\title{
Wild sage (Salvia officinalis) as a potential anti-malarial drug
}

\author{
Mutaz Akkawi ${ }^{*}$, Abd-Alkarem Sharif, Khaled Salem, Azzam Saleh, Qasem AbuRemeleh \\ From Challenges in malaria research \\ Basel, Switzerland. 10-12 October 2012
}

\section{Background}

During the intra-erythrocytic stage, Plasmodium parasites degrade hemoglobin resulting in ferriprotoporphyrin (IX) accumulation; toxic to the parasite [1].

$\beta$ - Hematin, a synthetic polymer made from ferriprotoporphyrin- IX is structurally, chemically and spectroscopically identical to purified hemozoin is used in in-vitro studies [1].

Resistance to Chloroquine, highlights the need for new drugs. Earlier attempts showed the effect of pyrimidine derivatives in in-vitro inhibition of $\beta$-hematin [2], and cisplatin complexes [3]. We concentrate on finding new molecules from natural products; (Salvia officinalis).

\section{Materials and methods}

Plant materials, collected from areas around Jerusalem, were dried at room temperature; leaves and stems separately grinded. Extraction was by soaking $5 \mathrm{gm}$ of dried plant parts in $40 \mathrm{ml}$ of $35 \%$ ethanol or ultrapure -water; left standing for about 24-hours. Extracts were then filtered using MN615- $\Phi 90 \mathrm{~nm}$ filter paper, rotary evaporated at $50^{\circ} \mathrm{C}$ then lyophilized to constant weight. Stock solutions were prepared in water.

\section{Semi-quantitative method}

The procedure was according to [4], ultra-pure water for negative control, chloroquine or Amodiaquine for positive control. The final precipitate of $\beta$-hematin dissolved in $200 \mu \mathrm{l}$ of $0.1 \mathrm{M} \mathrm{NaOH}$ to give alkaline hematin for spectroscopic quantification at $405 \mathrm{~nm}$.

\section{Results}

The efficiency of sage leaf extracts compared to controls is shown below. Each absorption value is the average of five experiments. The mechanism of inhibition is probably through formation of a complex between active compounds in these extracts and ferriheme; this complex prevents the formation of $\beta$-hematin.

\section{Conclusion}

The extract is a natural product and has been used in folk medicine with no reported toxicity.

Table 1

\begin{tabular}{|c|c|c|c|c|c|}
\hline \multirow[b]{2}{*}{ Negative Control ( $\mathrm{H} 2 \mathrm{O})$} & \multicolumn{4}{|c|}{ Absorbance } & \multirow{2}{*}{$\frac{\text { average }}{2.137}$} \\
\hline & 2.26 & 2.14 & 2.05 & 2.10 & \\
\hline Negative control 35\% ethanol & 2.22 & 2.01 & 2.21 & 2.23 & 2.167 \\
\hline Chloroquine $0.1 \mathrm{mg} / \mathrm{ml}$ & 0.045 & 0.047 & 0.055 & 0.179 & 0.071 \\
\hline Amodiaquine $0.1 \mathrm{mg} / \mathrm{ml}$ & 0.058 & 0.055 & 0.066 & 0.048 & 0.056 \\
\hline Chloroquine in 35\% ethanol $0.1 \mathrm{mg} / \mathrm{ml}$ & 0.055 & 0.062 & 0.055 & 0.059 & 0.057 \\
\hline Stock-leaf extract in 35\% ethanol $1 \mathrm{mg} / \mathrm{ml}$ & 0.060 & 0.057 & 0.047 & 0.069 & 0.058 \\
\hline Stock-leaf extract in 35\% ethanol $0.5 \mathrm{mg} / \mathrm{ml}$ & 0.044 & 0.074 & 0.059 & 0.060 & 0.059 \\
\hline Stock-leaf extract in water $1 \mathrm{mg} / \mathrm{ml}$ & 0.099 & 0.080 & 0.085 & 0.110 & 0.093 \\
\hline Stock-leaf extract in water $0.5 \mathrm{mg} / \mathrm{ml}$ & 0.378 & 0.162 & 0.270 & 0.255 & 0.266 \\
\hline
\end{tabular}

Department of Life Sciences, College of Science and Technology, Al-Quds University, 91999, Palestine 
Although the results for the extracts are lower than for the positive controls we must take into account the fact that the extracts are crude, we are already working on isolating the ingredients; results will be published in the near future.

Published: 15 October 2012

\section{References}

1. Rathore D: Strategies for malaria control. VBI Scientific Annual Report 2006, 49-53.

2. Aljazzar A, Abu-Remeleh Q, Alsharif A, AbulHaj M, Akkawi M: In vitro inhibition of $\beta$-hematin by 2,4-diamino-6-mercaptopyrimidine $\&$ 2mercaptopyrimidine. JChem Chem Eng 2010, 4(12).

3. Akkawi M, Aljazzar A, AbulHaj M, Abu-Remeleh Q: The effect of cis-2- $(1 \mathrm{H}-$ imidazole-2-yl)-1H-imidazole dichloro platinum (II) on the in-vitro formation of $\beta$-hematin. Br J Pharmacol Toxicol 2012, 3(2):65-69.

4. Deharo E, Garcia RN, Oporto P, Gimenez A, Sauvian M, Jullian V, Ginsburg H: A non-radiolabelled ferriproptophyrin (FP) IX biomineralisation inhibition test for high throughput screening of antimalarial drugs. ExpParasitol 2002, 100:252-256.

doi:10.1186/1475-2875-11-S1-P3

Cite this article as: Akkawi et al:: Wild sage (Salvia officinalis) as a

potential anti-malarial drug. Malaria Journal 2012 11(Suppl 1):P3.

\section{Submit your next manuscript to BioMed Central} and take full advantage of:

- Convenient online submission

- Thorough peer review

- No space constraints or color figure charges

- Immediate publication on acceptance

- Inclusion in PubMed, CAS, Scopus and Google Scholar

- Research which is freely available for redistribution

Submit your manuscript at www.biomedcentral.com/submit 